Hipotenusa : Journal of Mathematical Society

Volume 3 Issue 1 Year 2021

ISSN: 2716-3156

Website: https://hipotenusa.iainsalatiga.ac.id/index.php/hipotenusa/index

\title{
Socratic as Mathematics Learning Application for Differential Equations Concept
}

\author{
Wanda Nugroho Yanuarto ${ }^{1 *}$, Anton Jaelani ${ }^{1}$, Joko Purwanto ${ }^{1}$, \\ Mohamad Ikram Zakaria ${ }^{2}$ \\ ${ }^{1}$ Universitas Muhammadiyah Purwokerto, Indonesia \\ ${ }^{2}$ National University of Malaysia, Malaysia \\ * Corresponding Author, e-mail: wandanugrohoyanuarto@ump.ac.id \\ DOI: 10.18326/hipotenusa.v3i1.97-110
}

Article submitted : February 24, 2021

Article reviewed : April 22, 2021

Article published : June 1, 2021

\begin{abstract}
Technological improvements in the era of the Industrial Revolution 4.0 can be applied to learning mathematics as a medium of improving teacher performance. In addition, a pandemic situation forces teachers and students to implement online learning. One of the learning media that can help teachers in learning mathematics online is Socratic. The Socratic system generally consists of four basic components: acting humanely, thinking humanely, thinking rationally and acting rationally. For example, the Socratic can provide alternative solutions to the differential equations problems. Mathematics problems can be recorded by the Socratic through three main features:1) home screen, which is used to take pictures of solving the problem needed; 2) search results, the image that has been recorded will be searched for a solution through Socratic's artificial intelligence in internet database, and 3) an explanation, the search results that have been obtained, have their own explanation. Teachers and students as users may find the best solution for each explanation by the Socratic. Meanwhile, this study uses four stages of the literature review process:1) search for relevant literature, 2) evaluation and source selection, 3) identification of themes, and 4) outline of the structure of the writing. This paper systematically investigates the use of the Socratic as a technology application that can assist mathematical problems.
\end{abstract}

Keywords: socratic application technology, artificial intelligence (AI), teachers and students

\section{INTRODUCTION}

Technology and education are two sides of the coin. Education goes hand in hand with technological developments. Meanwhile, technology plays an important role in mathematics learning as well. Technology in mathematics education can be a learning medium (Durak \& Saritepeci, 2017). One of the technology-based learning media is Socratic. Socratic is a 
technology application that can be used to solve math problems. So that the use of Socratic can help students face the problems faced during learning (Russel, 2020).

In addition, with the Covid-19 pandemic issues, the role of technology is a tool that students must master. The change in the learning process from face-to-face systems to online learning has resulted in many problems (Sandolo 2020). In mathematics learning in particular, the role of learning media is to help students understand the concepts taught by teachers in online learning (Young 2018). Teachers need to introduce technology as an aid in learning. So that online learning that occurs can achieve the expected goals (Durak and Saritepeci 2017).

However, the use of existing technology is still an obstacle for students and teachers (Epstein 2018). It is because the existing technology is difficult to understand and unapplicable (Eastman, Iyer, \& Eastman, 2019). Therefore, Lavin et al., (2020), suggested teachers must be clever in choosing technology applications that easy for students to understand and practical to use. On the other hand, Sawang, O'Connor and Ali (2017) said that some of the technology that can be used in online learning are: Praxis, Kahoot, Edutainment Technology, and Socratic.

Socratic is much favoured by students and teachers because of the language of technology since it is easy to understand and practical in use (Paul \& Pepe, 2019). Subsequently, for instance, Ross et al. (2020), mentioned the Socratic could be used to find mathematical problems such as differential equations. The Socratic application works in three main features, namely: 1) home screen used to take pictures of the problem solving needed; 2) search results, the image that has been recorded will be searched for a solution through Socratic's artificial intelligence from internet database; and 3) an explanation, the search results that have been obtained, then have an explanation of each.

Therefore, based on the explanation above, it can be concluded that technology is an important part of education today. Online learning patterns that occur require students and teachers to learn and understand technology (Apriyanti et al., 2019). So, the role of technology can be an aid and other learning resources in the learning process (Unser, 2017). This article discusses the role and strength of technology in education, and specifically the use of the Socratic application in helping students and teachers in differential equations concepts in mathematics learning.

\section{METHOD}

Our study uses the Onwuegbuzie and Frels (2016) literature review construct. This study focuses on the strengths of Socratic technology applications in learning. The strength of the Socratic technology application could be used for teachers and students. In addition, this study 
focuses on how Socratic can become one of the must-have technology applications for learning. Some of the phases for the literature review are as follows:

\section{Search for Relevant Literature}

Search for literature sources in accordance with the focus of the study is an effective way of studying literature (Helmericks, Nelsen, \& Unnithan, 2017). In addition, Nakano and Muniz (2018) explain that the focus chosen must have different characteristics and uniqueness. This study focuses on learning technology applications and Socratic technology applications. This study selects articles that are suitable for the focus of the study.

\section{Evaluate and Select Sources}

Evaluation and selection of literature sources have advantages in the literature review. According to Al-shaikh et al. (2019), explaining source selection must be seen from the quality of the publication. Reliable publications could be used as a reference for choosing the appropriate articles (Rowland, Hub, \& Services, 2018). This stage evaluates 30 articles that have been selected. The evaluation process produced 14 articles that were in accordance with the focus of the study and had reliable quality articles from the index (DOAJ, Scopus, and WOS).

\section{Identify Themes}

The stage of identifying themes is a continuation of the evaluation and selection of articles (Rodriguez, 2017). In addition, George (2017) said the theme taken as a summary of the evaluation of the articles that had been selected. In this study, four themes were obtained: 1) technology applications do in education, 2) artificial intelligence (AI) technology, 3) a musthave of Socratic application technology, and 4) Socratic as a technology application for teachers and students.

\section{Outline the Review's Structure}

The final stage in the literature review was to create an outline structure. According to Anon (2016), an outline is one way to make an article. In addition, Bolderston (2018) explains that writing constructs could be seen from the previous theme chosen. William (2016) explanation also illustrates that the theme is an essential reference in making the outline structure. So, in this study, the outline structure is made according to the chosen theme. The outline in this study is in figure 1. 


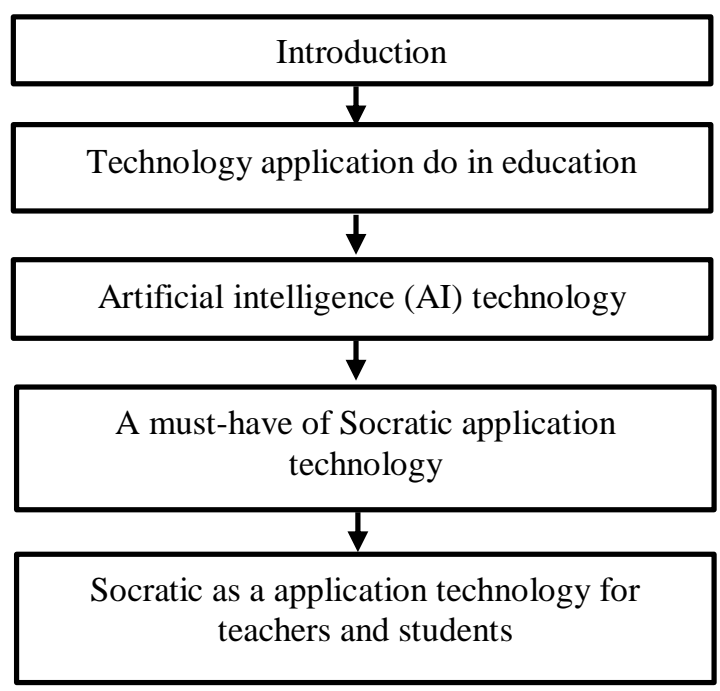

Figure 1. The outline review-structure

\section{RESULTS AND DISCUSSION}

\section{What do Technology Applications do in Education?}

The application of technology in education has many roles. Harris et al. (2020), in the era of the Industrial Revolution 4.0, technology has become the most essential component in solving daily human problems. Furthermore, Bhattacharjee and Deb (2016), the technology used in the classroom is a source for students to find solutions to solving conceptual problems.

The application of technology applications in the classroom can be used in several ways. Moore (2020) describes seven aspects that technology can do in education, 1) distance learning; 2) use of technology to share material; 3) e-report cards; 4) students' enrollment online; 5) attendance system; 6) the school financial system; and 7) e-library. Another opinion, Prensky (2018) explains the function of technology in education to be a benchmark for the success of education today. Schools with good access to technology think that educational success will be successful.

Technology applications that can be used in learning require teachers and students thoroughly. Ranasinghe and Leisher (2019), the pandemic situation nowadays forces teachers to limit interactions with students and do online learning. Furthermore, Connie (2020), with the existence of video-based communication technology, it is easier for teachers to provide material even though it is a virtual class. Moreover, existing technology applications can improve student understanding in class.

Technology applications can also be used to share concept material (Bialo \& SivinKachala, 2018). The implementation of online learning also impacts the provision of concepts. Gorra et al., (2016) explain that with technology applications, teachers can deliver material to 
students by uploading it on a technology portal. Students anywhere and anytime can download and study it any time.

Also, social restrictions in the era of the Covid-19 pandemic have forced teachers to do all digital-based activities, one of which is student learning outcomes. According to Solomon (2018), the use of technology can make e-report cards. The use of e-report cards in education during social restrictions is one way to reduce teacher and student interactions. Teachers use Muir-Herzig (2020) e-report card technology to write student achievements digitally. Teachers can send e-report cards to parents via email or the school's official website.

Online learning certainly uses technology to record student attendance. The role of technology in the student attendance system helps teachers record students present in digital learning. Pedro (2019) said that technology for recording student attendance has abilities that can help teachers in carrying out online-class administration. Besides, Clarck (2019) digital presence system makes students believe in the actual implementation of digital learning.

Furthermore, technology applications can help teachers in other school administration activities, such as finance and libraries. Francis (2017) said that transparent school finances could be done through technology. Also, Hutchison (2018), a library that continues to operate even though there are no school activities, is a solution for students to continue learning. Digital libraries help students to find learning resources. Moreover, for the sake of teacher learning, they also need a digital library to find references for teaching purposes.

\section{Socratic in an Artificial Intelligence (AI) Technology System}

AI provides machines such as computers with the ability to display behaviours considered intelligent as human thought processes. Durak and Saritepeci (2017) that AI makes it easy for humans to do things that are concise and fast. Besides, Prensky (2018), artificial intelligence technology provides useful experiences for humans in shortening the time so that their work is completed quickly. According to Kelvin (2020), in general, artificial intelligence technology has four main components: 1) acting humanly; 2) Humanly thinking; 3) think rationally; and act rationally.

Socratic with AI provides perfect services for teachers and students. Solving the requested problem will find a solution by human-like thinking (Lavin et al., 2020). So that Socratic AI can provide more explanation for both teachers and students (Moore, 2020). In general, the Socratic work process consists of four basic AI components. Acting Humanly, a Socratic system that can act like humans. Unser (2017), explains that Socratic will respond to alternative answers according to the user's instructions. Thinking Humanly, a system that can think like humans. Connie (2020) says Socratic can provide various alternative answers adapted to human 
thought processes. Think Rationally, a system that can think rationally. Some of the alternative answers given by the Socratic will describe a rational thought process like humans (Sandolo, 2020). Act Rationally, a system that can act rationally. The solution action provided by the Socratic employing various solutions indicates the Socratic can act rationally. This action process is based on various opinions of experts who explain alternative solutions to previous problems (Bialo \& Sivin-Kachala, 2018).

\section{Socratic is a Must-Have Application for School Teachers and Students}

According to Kim (2019), education technology in the industrial revolution 4.0 era is a must-have for schools. Teachers and students as users of education use technology all the time. Poynter (2020) explains the role of teachers in the 21st-century era as technology users. Furthermore, Erokhin (2018) said that the available technology is one of the learning resources for digital learning. Also, Bhatti and Mohiuddin (2019) explain that Socratic media is an example of learning resources in the digital era. Online learning that is carried out gives a clear picture that technology is very important to help students' independent learning process (Zaslavsky \& Tari, 2018).

Socratic learning media have been carried out in many countries, such as Indonesia, Malaysia, Egypt, Thailand, and Singapore (Patil, Karhe, \& Aher, 2019). Some researches results say that Socratic can help students solve algorithmic problems and other sciences (Goldberg, 2016). Besides, Zaslavsky and Tari (2018) explain the use of Socratic as a learning media provides $78 \%$ effectiveness in student learning. Subsequently, Socratic digital media also helps teachers prepare for digital learning (Bolat, 2019). Also, the ease of using Socratic media is one of its positive values. Sampieri (2018) explains that this digital media has ease of use to be interested in using it. Besides, existing AI technology allows Socratic to update information on teachers' problems (Norman, 2019). The extensive network within the Socratic search system provides teachers with many opportunities to learn many concepts (Bolat, 2019). Mayisela (2018) said that solving various problems is also an added value for students to enrich their knowledge.

\section{Discussion}

Virtual online learning in the past two years has had a broad impact on applying technology to education. Russel (2020) explains that the use of applications is sought after by students to help them understand the material in the online class. Besides, Young (2018) said that technology applications sought after by students are easy to use and can be understood by all students. Pedro (2019), Socratic as the application technology in online learning was success help students do the class. 
Hipotenusa Journal, 3 (1), June 2021

Wanda Nugroho Yanuarto, Anton Jaelani, Joko Purwanto, Mohamad Ikram Zakaria

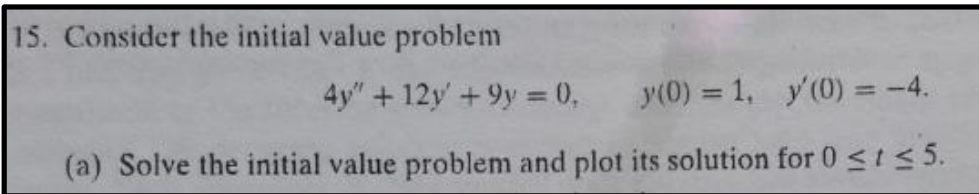

Figure 2. The problem

The sample problem from students, as Figure 2, could be solved by the Socratic technology. Students and teachers can find alternative solutions to the problems. Many solutions will show, and students can identify the proper solution. Teachers also can find the good way for teaching the problem in the classroom. According to Moore (2020), Socratic has three main features: the home screen, browsing results, and explainers. In this feature, users can see three services on Socratic: camera, voice and chat. According to Kelvin (2020), a camera service, users can use this service by photographing problems that will be sought for Socratic solutions (see Figure 2). Solomon (2018) says that the photos used can be reduced and adjusted as needed (see Figure 3).

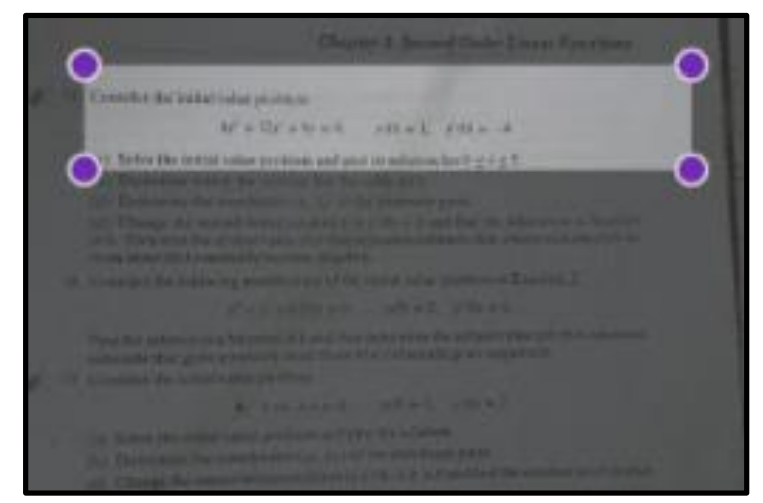

Figure 3. Snap and crop the preferred question

Browsing Results, this second feature can provide useful information about alternative results obtained by Socratic from the given problem. Patil et al. (2019) explain that the photos provided depend on the quality of the photos taken. Socratic legibility is seen from the image quality of the photos. Also, Mayisela (2018) explains that the image results will be read as one data that Socratic will look for a solution (See Figure 4). 


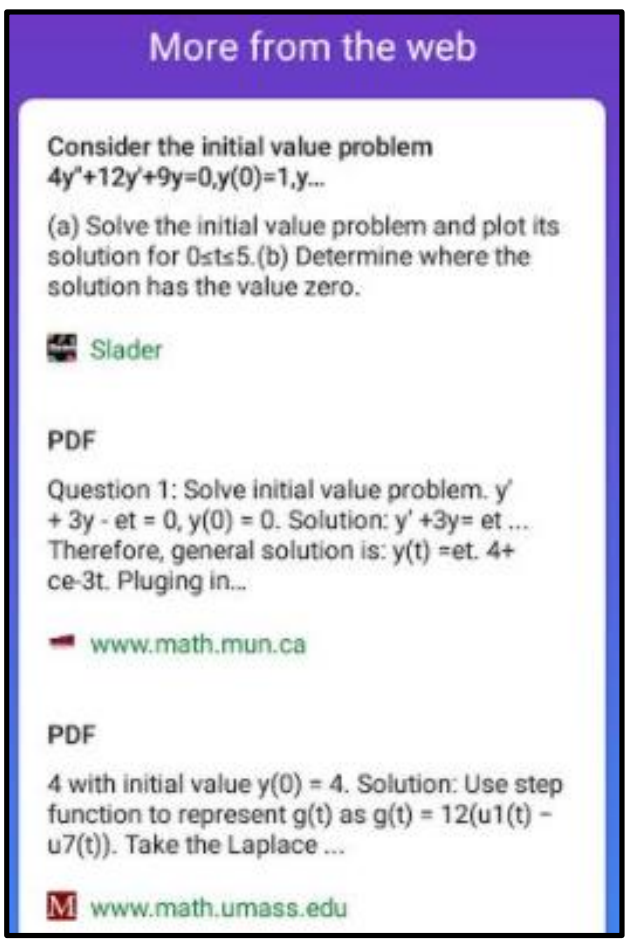

Figure 4. The browsing results

Explainers, following Traxler (2019), Socratic's explanation can be in the form of a brief explanation or the form of a video. The Socratic explains the various available ways. Sampieri (2018) says the Socratic explanation can help students re-learn the class material. Also, Bhatti and Mohiuddin (2019), experts' opinions regarding the material solutions provided can be used as a guide for Socratic to explain the results of problems submitted by users. Besides, Zaslavsky and Tari (2018), learning with Socratic interactive media provides a new student experience. Teachers can also explain concepts in class based on search results from Socratic technology (See Figure 5). 


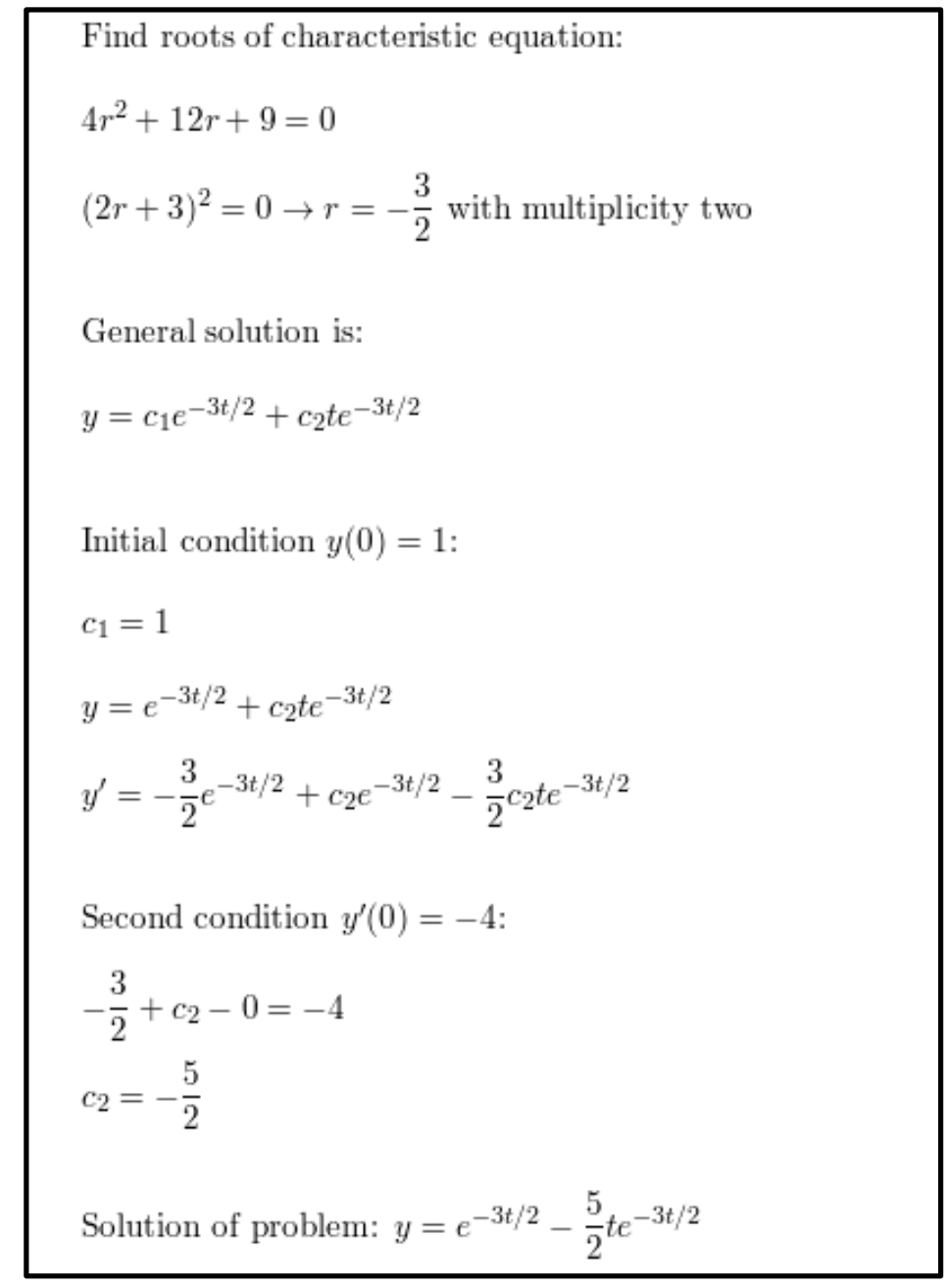

Figure 5. The sample of explainers show from slader.com

Some of the alternative solutions that can be obtained from Socratic technology have many characteristics and resources (See Figure 4). Students and teachers can find which solution most resembles the problem at hand. The role of the teacher, in this case, is able to sort out which the proper solution that students face (Goldberg 2016).

\section{Socratic is a Technology Application for Teachers and Students}

Socratic's AI technology has many advantages. Naismith et al., (2016) mention three advantages of Socratic: 1) get help at any moment, 2) understand the underlying concepts, and 3) browse helpful topic explanations for quick references. Also, Goldberg (2016) AI technology has many advantages that can help humans. One of them is understanding what humans understand. The thinking process carried out by human intelligence technology can process information, such as the brain's process of processing information. So, Kim (2019) said that technology could be a good friend of humans and be used for positive things. On the education side, human intelligence technology can be applied in learning media. 


\section{Get Help at Any Moment}

Socratic's AI technology can be used at any time. Both teachers and students can use Socratic. Norman (2019) explains that teachers can use Socratic for teaching preparation, while students can use it to find other information sources besides what the teacher says. Also, Weberknechte (2019) said that Socratic technology is one way for students to find solutions to classroom problems at hand. Information technology and the growing development of education today provide a special space for the Socratic to help students understand learning. Understand the Underlying Concepts

The teacher can give instructions manually to students from face-to-face learning in class. The AI technology adopts the human mindset to receive information. Poynter (2020) says that artificial intelligence technology has the same role as human intelligence in receiving information. The rest, Erokhin (2018) explains that the Socratic has the same role in receiving information. Receipt of the information then processed through technological devices to find alternative solutions to the received problems.

\section{Browse Helpful Topic Explanations for Quick Reference}

AI technology has the characteristic of being able to search for various relevant information. McGibbon et al. (2019) said the explanation obtained from search results on the Google page has various references. Socratic technology takes several alternative solutions to problems from various sources from experts. Students can take the options from several experts. Thus students can understand the problem from various points of view. Bolat (2019) says that providing information from experts helps students understand the problems at hand. Furthermore, Traxler (2019) explained that student learning resources have many advantages in today's technological era. The AI technology in learning media can be a source of student learning.

\section{CONCLUSION}

The industrial revolution 4.0 era has an impact on the application of technology in mathematics education. One of them is in the mathematics learning concepts. The Socratic technology application is one of the learning media that employed AI technology. AI technology provides convenience and change for humans, especially in education. Teachers and students are helped by AI technology to solve problems related to mathematics learning. For example, in the Differential Equations mathematics concept, Socratic can provide alternative solutions to the differential Equations problems. Mathematics problems can be recorded by the Socratic through three main features:1) home screen, which is used to take 
pictures of solving the problem needed; 2) search results, the image that has been recorded will be searched for a solution through Socratic's artificial intelligence in internet database, and 3) an explanation, the search results that have been obtained, have their own explanation. Therefore, Socratic application technology provides advantages and benefits, such as 1) get help at any moment, 2) understand the underlying mathematics concepts, and 3) browse helpful topic explanations for quick references.

\section{REFERENCES}

Al-shaikh, A. M., Bemile, R. K., Gborgla, J., Mensah, P. O., Boateng, V., Ansa, H. O., Prasanna, P. M. (2019). E-Learning Literature Review. Journal of Research in Information Technology, 3(13), 12-35.

Anon, C. (2016). Literature Review. Journal of the Water Pollution Control Federation, 48(6), 997-1008.

Apriyanti, D., Syarif, H., Ramadhan, S., Zaim, M., \& Agustina, A. (2019). Technology-Based Google Classroom In English Business Writing Class. Advances in Applied and Pure Mathematics, 301(8), 689-694. https://doi.org/10.2991/icla-18.2019.113

Bhattacharjee, B., \& Deb, K. (2016). Role of ICT in 21 st Century's Teacher Education. International Journal of Education and Information Studies, 6(1), 1-6.

Bhatti, S., \& Mohiuddin, W. (2019). The Cell Phone Technology. Journal of Advanced Research Design, 4(2), 221-236.

Bialo, E., \& Sivin-Kachala, J. (2018). The effectiveness of technology in schools: a summary of recent research. Journal of Advanced Research Design, 25(1), 51-57.

Bolat, E. (2019). Why to Use Mobile Technology? Journal of Educational Computing Research, 4(20), 445-459.

Bolderston, A. (2018). Writing an Effective Literature Review. Journal of Medical Imaging and Radiation Sciences, 39(2), 86-92. https://doi.org/10.1016/j.jmir.2008.04.009

Clarck, J. (2019). Technology in Education: A System View. Journal of Educational Social Studies, 4(2), 54-66.

Connie, C. (2020). Teacher Perceived Impact of Technology on Elementary Classrooms and Teaching. Journal of Digital Learning in Teacher Education, 7(2), 147-173.

Durak, H., \& Saritepeci, M. (2017). Investigating The Effect of Technology Use in Education on Classroom Management within The Scope of The FATİH Project. Cukurova University Faculty of Education Journal, 46(2), 441-457. https://doi.org/10.14812/cuefd.303511

Eastman, J. K., Iyer, R., \& Eastman, K. L. (2019). Interactive Technology In The Classroom: An Exploratory Look At Its Use And Effectiveness. Contemporary Issues in Education 
Research (CIER), 2(3), 31. https://doi.org/10.19030/cier.v2i3.1084

Epstein, A. S. (2018). Using technology appropriately in the preschool classroom. HighScope Extensions, 28(1), 1-12.

Erokhin, V. V. (2018). The use of mobile learning in the educational process of universities. Journal of Perspectives in Applied Academic Practice, 4(2), 55-69. https://doi.org/10.18411/lj-10-2018-146

Francis, J. (2017). The Effects of Technology on Student Motivation and Engagement in Classroom-Based Learning. Technology On Student Motivation And Engagement In Classroom-Based Learning, 4(2), 1-60.

George, M. (2017). Literature Review Purpose. Western Sydney University Library, 3(July), 112.

Goldberg, S. (2016). An Introduction to Mobile Robotics. Journal of Applied Quantitative Methods, 5(3), 24-39.

Gorra, V. C., Bhati, S. S., \& Bhati, S. (2016). Students' perception on use of technology in the classroom at higher education institutions in Philippines. Journal of Education and ELearning, 4(3), 2321-2454.

Harris, J. L., Al-Bataineh, M. T., \& Al-Bataineh, A. (2020). One to One Technology and its Effect on Student Academic Achievement and Motivation. Contemporary Educational Technology, 7(4), 368-381. https://doi.org/10.30935/cedtech/6182

Helmericks, S. G., Nelsen, R. L., \& Unnithan, N. P. (2017). The Researcher, the Topic, and the Literature: A Procedure for Systematizing Literature Searches. The Journal of Applied Behavioral Science, 27(3), 285-294. https://doi.org/10.1177/0021886391273004

Hutchison, D. (2018). Technolog in the Mathematics Classroom. Journal of Emerging Trends in Educational Research and Policy Studies (JETERAPS), 14(June), 11-24.

Kelvin, J. (2020). Digital technologies in the classroom. Journal for Research in Math Education, 3(2), 11-23.

Kim, P. (2019). Future Trends in Mobile Technology Development: What Can We Expect in the Next 5, 10, and 15 Years? Journal of Educational Computing Research, 4(3), 221235.

Lavin, A. M., Korte, L., \& Davies, T. L. (2020). The impact of classroom technology on student behavior. Journal of Technology Research, 2(4), 1-13.

Mayisela, T. (2018). The potential use of mobile technology: Enhancing accessibility and communication in a blended learning course. South African Journal of Education, 33(1), 1-18. https://doi.org/10.15700/saje.v33n1a629 
McGibbon, T., Hosmer, C., Jeffcoat, C., \& Davis, M. (2019). Use of Mobile Technology for Information Collection and Dissemination. Journal of Science Teacher Education, 4(2), 22-39.

Moore, T. (2020). Integrating Technology into the Classroom. Journal for Research in Mathematics Education, 3(4), 1-13.

Muir-Herzig, R. G. (2020). Technology and its impact in the classroom. Computers and Education, 42(2), 111-131. https://doi.org/10.1016/S0360-1315(03)00067-8

Naismith, L., Lonsdale, P., Vavoula, G., \& Sharples, M. (2016). Literature Review in Mobile Technologies and Learning. Journal of Educational Computing Research, 8(4), 31-44.

Nakano, D., \& Muniz, J. (2018). Writing the literature review for empirical papers. Journal of Literacy Research, 28(3), 21-36. https://doi.org/10.1590/0103-6513.20170086

Norman, C. (2019). mHealth for Development: The Opportunity of Mobile Technology for Healthcare in the Developing World. Journal of Educational Computing Research, 46(1), $51-70$.

Onwuegbuzie, A. J., \& Frels, R. (2016). Seven Steps to a Comprehensive Literature Review. Journal of Educational Social Studies, 23(2), 48-64.

Patil, C. S., Karhe, R. R., \& Aher, M. A. (2019). Development of Mobile Technology: A Survey. International Journal of Advanced Research in Electrical, Electronics and Instrumentation Engineering, 1(5), 374-379.

Paul Chow, \& Pepe, T. M. (2019). Teacher's attitudes towards technology in the classroom. Journal for Research in Mathematics Education, 4(April), 21-38.

Pedro, B. (2019). Technology in the Classroom. Journal of Digital Learning in Teacher Education, 84(4), 487-492.

Poynter, R. (2020). The Utilization of Mobile Technology and Approaches in Commercial Market Research. Journal of Emerging Trends in Educational Research and Policy Studies (JETERAPS), 4(2), 11-20. https://doi.org/10.5334/bar.b

Prensky, M. (2018). The Role of Technology in Teaching and the Classroom. Journal of Advanced Research Design, 34(3), 127-139. https://doi.org/10.4135/9781483387765.n13 Ranasinghe, A. I., \& Leisher, D. (2019). The Benefit of Integrating Technology into the Classroom. International Mathematical Forum, 4(40), 1955-1961.

Rodriguez, A. R. (2017). Literature Review. American Journal of Medical Quality, 17(5), 206219. https://doi.org/10.1177/106286060201700509

Ross, S. M., Morrison, G. R., \& Lowther, D. L. (2020). Educational Technology Research Past and Present: Balancing Rigor and Relevance to Impact School Learning. Contemporary 
Educational Technology, 1(1), 17-35. https://doi.org/10.30935/cedtech/5959

Rowland, D. R., Hub, T. L., \& Services, S. (2018). Literature Review A Short Guide for research students. Journal of Learning Hub, University of Queensland, 4(2), 21-30.

Russel, M. (2020). The Impact of Educational Technology on Learner Interactions: a Multiple Case Study of Elementary Classroom. Journal of Advanced Research Design, 3(May), 465-478. https://doi.org/10.1093/oseo/instance.00220925

Sampieri, R. H. (2018). Mobile technologies for food security, agriculture and rural development. Journal for Research in Mathematics Education, 5(3), 634-649.

Sandolo, L. (2020). How can the use of technology enhance writing in the classroom? Education Masters, 4(2), 1-44.

Sawang, S., O'Connor, P., \& Ali, M. (2017). IEngage: Using Technology to Enhance Students' Engagement in a Large Classroom. Journal of Learning Design, 10(1), 11. https://doi.org/10.5204/jld.v9i3.292

Solomon, K. (2018). Teachers and 1:1 technology in classroom activities: A quantitative study comparing perceptions and stage of adoption. Journal for Research in Mathematics Education, 3(2), 55-78.

Traxler, J. (2019). Students and mobile devices. ALT-J: Research in Learning Technology, 18(2), 149-160. https://doi.org/10.1080/09687769.2010.492847

Unser, C. E. (2017). A Study on The Positives and Negatives of Using Technology In The Classroom A S. Journal for Research in Mathematics Education, 2(3), 41-58.

Weberknechte, A. Der. (2019). School Technology Action Report. Journal of Educational Computing Research, 5(2), 46-59.

William, J. (2016). Literature Review. The American Review, 76(3), 83-94.

Young, R. (2018). Using Technology Tools in the Public School Classroom. Journal Basic of Education, 2(2), 1-59.

Zaslavsky, A., \& Tari, Z. (2018). Mobile computing: Overview and current status. Journal of Research and Practice in Information Technology, 30(2), 42-52. 